\title{
Nasal NO: normal values in children age 6 through to 17 years
}

\author{
V.M.D. Struben*, M.H. Wieringa*, C.J. Mantingh*, C. Bommeljé*, M. Don\#, \\ L. Feenstra* and J.C. de Jongste
}

\author{
ABSTRACT: The present study is an assessment of normal values of nasal nitric oxide (nNO) in \\ healthy children.
}

Healthy children aged between 6-17 yrs were recruited from three schools in Rotterdam (The Netherlands). Breath was held for $10 \mathrm{~s}$, while air was extracted from one nostril at $700 \mathrm{~mL} \cdot \mathrm{min}^{-1}$. The mean $\mathrm{nNO}$ value at the response plateau after 7-10 s was recorded and the average of three measurements was used.

In total, 340 children participated; the male:female ratio was 156:184. Three reliable measurements were available in $85 \%$ of the children. The nNO concentrations were distributed normally (mean 449 ppb, SD 115). They were not associated with sex, passive smoking or body mass index. In children aged $<12$ yrs nNO correlated positively with age, history of adenoidectomy and ambient NO. In children aged $\geqslant 12$ yrs ambient NO was the only significant modifier. Prediction rules for nNO values in children were formulated.

In conclusion, the current study presents normal values for nasal nitric oxide in children, which can be used to assess the value of nasal nitric oxide in respiratory illnesses.

\section{KEYWORDS: Children, nasal nitric oxide, normal values}

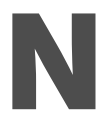

itric oxide (NO), a potent biological mediator, was first demonstrated to be present in orally exhaled air by GustafsSOn et al. [1]. Two years later Alving et al. [2] observed the presence of $\mathrm{NO}$ in the human nasal airways, and in the paranasal sinuses, in much higher concentrations compared with the lower airways. Studies in healthy adults indicate that $\mathrm{NO}$ in nasal air is mainly produced in the epithelial cells of the nasal cavity, particularly in the paranasal sinuses [3]. NO is known to be involved in the local host defence of the upper airways and acts as an airborne messenger and as a regulator in mucociliary function in the nasal airway [4-7]. In addition nasal $\mathrm{NO}(\mathrm{nNO})$ is affected by inflammation of the upper airways [8-12].

Measurement of $\mathrm{nNO}$ can easily be performed and can be used to screen for disease or to monitor treatment effects. However, the uses of $\mathrm{nNO}$ measurements within clinical practice are still limited. On the one hand, the effects of different physiological and pathological conditions on nNO still require further research. On the other hand, there is a lack of consensus on measurement techniques, which consequently lead to different findings of $\mathrm{nNO}$ concentrations in different airway illnesses, such as sinusitis [10,
13], polyposis nasi $[8,10]$ and (allergic) rhinitis [9, 14-16]. Exceptions are cystic fibrosis (CF) [17-22] and primary cilliary dyskinesia [23-26]. It is well established that the nNO levels in these patients are extremely low and are independent of the measurement methods used.

There is only one study on normal values of nNO in healthy children [27]. The assessment of normal values of $\mathrm{nNO}$ may be important for determining the role of $\mathrm{nNO}$ as a marker of inflammatory disorders of the upper airways. The reported effects of inflammation on nNO are not consistent [10, 13, 25, 28-32]. The conclusions of the various studies may differ because of methodological factors, including different sampling methods, sampling flow-rate and the influence of ambient NO. In previous studies, the effects of airway diseases and treatment on $\mathrm{nNO}$ have been compared with normal nNO levels obtained from relatively small control groups, which are not suitable to assess normal values, and do not necessarily represent a sample of the general population $[11,14,33]$. Therefore, the current authors aimed to collect normal values for $\mathrm{nNO}$ in a large population of healthy children aged between 6-17 yrs, using a previously validated method [34].
AFFILIATIONS

*Dept of Otolaryngology, and

"Dept of Paediatric Respiratory

Medicine, Erasmus MC, Rotterdam,

The Netherlands.

\#Dept of Paediatrics, School of Medicine DPMSC, University of Udine, Italy.

CORRESPONDENCE

J.C. de Jongste

Erasmus medical centre/Sophia

Children's Hospital

Dept Paediatric Respiratory Medicine

Dr. Molewaterplein 60

3015 GD Rotterdam

The Netherlands

Fax: 31104636811

E-mail:

j.c.dejongste@erasmusmc.n

Received:

February 102005

Accepted after revision:

May 042005

\section{SUPPORT STATEMENT}

The participation of M. Don in the

study team was supported by a grant from the Italian Nitric Oxide Club and Valeas s.p.a, Milan, Italy. 


\section{METHODS}

\section{Subjects and setting}

Children (aged 6-17 yrs) from two primary and one secondary school were invited to participate. All parents and children $(\geqslant 12$ yrs of age) were asked to fill out a questionnaire based on the International Study of Asthma and Allergies in Childhood (ISAAC) core questionnaire [35, 36]. This was extended with questions on inclusion and exclusion criteria and potential confounders (sex, age, height, weight, body mass index (BMI), history of ear, nose and throat surgery and passive smoking). The inclusion criteria were: age 6-17 yrs, written consent from parents and the child (aged $\geqslant 12$ yrs). Exclusion criteria were: physical exercise immediately before the NO measurement; active smoking; allergy and/or asthma (based on ISAAC core questionnaire); airway influencing medication (e.g. inhaled corticosteroids, nasal decongestives); chronic airway disease (e.g. CF, primary ciliary dyskinesia); and recent ( $<3$ months) adeno- and/or tonsillectomy.

\section{Nasal NO measurements}

The nNO was measured with a NIOX chemiluminescence analyser (Aerocrine, Solna, Sweden). The air was sampled with a flow of $700 \mathrm{~mL} \cdot \mathrm{min}^{-1}$ from the nostril with the best patency [34]. Calibration of the equipment was performed every 14 days using $100 \%$ nitrogen to zero and with a certified calibration gas (NO, $2120 \mathrm{ppb})$. The NO signal was sent to a computer data acquisition program (NIOX, nasal mode; Aerocrine) that displayed real-time measurements.

The nNO was measured during breath-hold after a deep inspiration. An NO-inert olive was placed firmly against one nostril. The olive was connected to an adjustable vacuum pump (custom made) to obtain a flow of $700 \mathrm{~mL} \cdot \mathrm{min}^{-1}$ [34]. From a side port a sampling tube was led to the NIOX. Subjects were asked to take a deep breath and hold it for $10 \mathrm{~s}$. The average nNO concentration was calculated at the plateau between 7-10 s after breath-hold (fig. 1). Preliminary experiments indicated that with this technique, the soft palate was closed as evidenced by absence of $\mathrm{CO}_{2}$ in the aspirated air. Any leakage was evident from an increase in $\mathrm{CO}_{2}$ and a sudden drop in $\mathrm{nNO}$. The manoeuvre was performed in

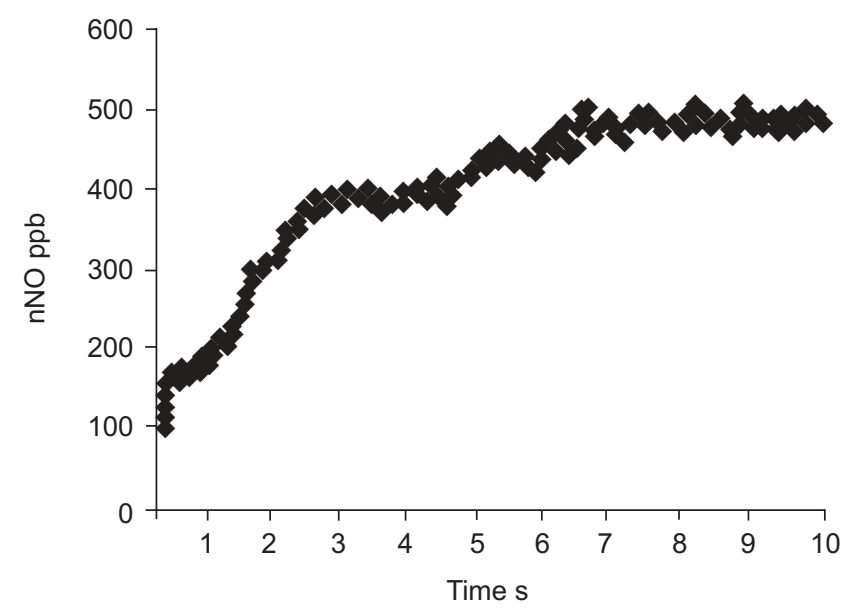

FIGURE 1. Example of on-line nasal nitric oxide (nNO) measurement during $10 \mathrm{~s}$ of breath-hold and aspiration flow of $700 \mathrm{~mL} \cdot \mathrm{min}^{-1}$. triplicate. To obtain three correct measurements a maximum of six attempts were made. Before every measurement the ambient NO concentration was recorded. The Ethical Committee of the Erasmus Medical Centre (Rotterdam, The Netherlands) approved the study protocol.

\section{Statistical methods}

The nNO concentrations were expressed as the mean of three measurements. For the analysis of the relationship between $\mathrm{nNO}$ and potential confounders, univariate analyses were performed. When the univariate analysis appeared to be significant ( $p<0.10 ; 90 \%$ confidence interval) the variables were included in a multivariate analysis. For the multivariate analysis different linear and quadratic models were used to test $\mathrm{nNO}$ concentrations in healthy children as a function of covariates. Algorithms were formulated to predict normal nNO in healthy children by fitting linear and quadratic models.

\section{RESULTS}

\section{Study population}

In total, 1,343 subjects were invited by letter to participate, and of these, 606 children (58\%) responded. The response at the secondary school $(36 \%)$ was lower than at the two primary schools (61\% and 57\%, respectively). In total, 340 children (56\%) aged between 6-17 yrs met the inclusion criteria and were enrolled (156 male and 184 female; fig. 2). There were 266 $(44 \%)$ children excluded from the study (128 wheezed, 154 sneezed, 66 smoked, 69 other health disorders; numbers overlap). Most children were Caucasian (92.4\%). The mean (SD) BMI was 18.5 (3.1). A total of $41(12.1 \%)$ of the enrolled children had a history of adenoidectomy, but none occured 3 months prior to the measurements being taken.

\section{Nasal NO values}

From the study population, 289 children successfully performed the nNO measurements (mean age $11.6 \mathrm{yr}$ ), with 51 $(15 \%)$ having problems with performing the measurements (mean age $11.2 \mathrm{yr}$ ), including difficulties in maintaining an adequate palatal closure and failure to achieve a stable plateau. This group was not significantly different from the whole study group. The values of nNO were normally distributed (mean 449 ppb; SD 115; fig. 3). The ambient NO ranged from 5-182 ppb, with a median of $43 \mathrm{ppb}$. The $\mathrm{nNO}$ values were independent of sex, passive smoking, height, weight or BMI.

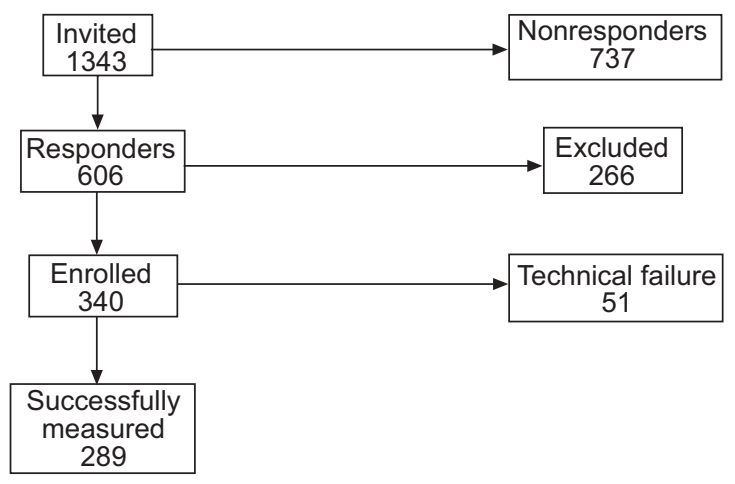

FIGURE 2. Flow chart of the study. 


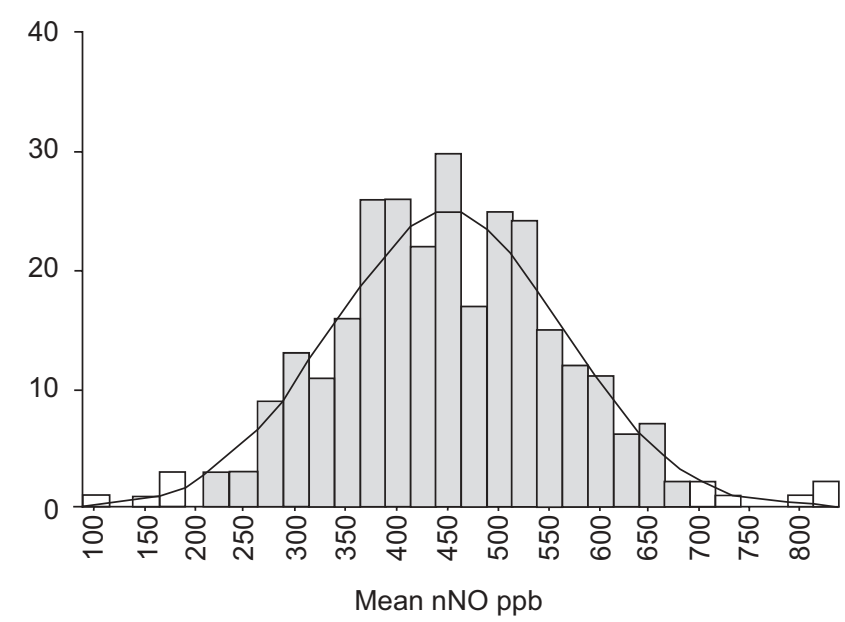

FIGURE 3. Distribution of mean nasal nitric oxide $(\mathrm{nNO})$ values $(\mathrm{ppb})$ in healthy children aged between $6-17$ yrs. $\square:$ : $95 \%$ of the subjects. Mean=449.3; standard deviation=114.9; $\mathrm{n}=289$.

Several models were fitted to describe the relationship between $\mathrm{nNO}$ and age and other covariates. Plotting $\mathrm{nNO}$ against age suggested an increase towards a plateau at older age $(<12 \mathrm{yrs}$; fig. 4). Therefore, a quadratic model was fitted but did not appear to contribute significantly in describing the relationship. A standard linear model did not fit the data sufficiently. Subsequently, a linear model depending on age, with two different slopes connecting at one point was fitted with a nonlinear least squares method. The model predicted the intersection of the two slopes at the age of 11.2 yrs. Taking into account the interaction with age the current authors proposed to stratify for age in two groups in the algorithm for predicting $\mathrm{nNO}$.

In children aged $<12$ yrs the mean $\mathrm{nNO}$ value correlated positively with age (adjusted $\beta=11.5 ; \mathrm{p}<0.01$ ), was modified by a history of adenoidectomy in the past (adjusted $\beta=-57.5$; $\mathrm{p}=0.02$ ), and correlated positively with ambient NO (adjusted $\beta=0.50 ; p<0.01)$. These associations were nonsignificant in children aged $\geqslant 12$ yrs except for ambient NO. Two prediction rules for $\mathrm{nNO}$ value in healthy children were derived. The equations predict the mean $\mathrm{nNO}$ concentration corrected for

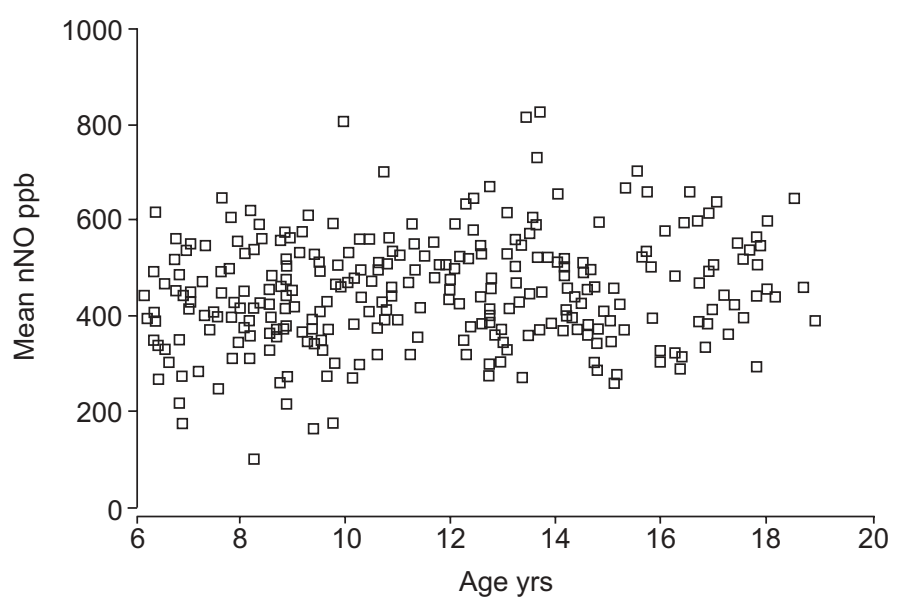

FIGURE 4. Nasal nitric oxide (nNO) values in healthy children by age. age in years, history of adenoidectomy (yes $=1$ and no=0) and ambient NO (in ppb) in healthy children (on the condition of the inclusion criteria described previously).

Prediction rule for $\mathrm{nNO}$ age $<12$ :

$$
\begin{gathered}
\mathrm{nNO}=314.6+11.5 \times \text { age }-57.5 \times \text { history of } \\
\text { adenoidectomy }+0.5 \times \text { ambient } \mathrm{NO}
\end{gathered}
$$

Prediction rule for $\mathrm{nNO}$ age $\geqslant 12$ :

$$
\begin{aligned}
\mathrm{nNO}= & 452.6-2.9 \times(\text { age }-12)-16.0 \times \text { history of } \\
& \text { adenoidectomy }+0.5 \times \text { ambient } \mathrm{NO}
\end{aligned}
$$

For example, the approximate nNO concentration of a child aged 10 yrs who has never had an adenoidectomy and has an ambient $\mathrm{NO}$ of $15 \mathrm{ppb}$ will be:

$$
314.6+(11.5 \times 10)-(57.5 \times 0)+(0.5 \times 15)=437.1 \mathrm{ppb}
$$

\section{DISCUSSION}

The present study assessed $\mathrm{nNO}$ in a large group of healthy children. In 289 children aged 6-17 yrs, nNO was normally distributed and depended on ambient $\mathrm{NO}$ and, only in those aged $<12$ yrs, on age and history of adenoidectomy. Sex, passive smoking, BMI, weight and height did not influence nNO. The current study is one of the first studies on normal values of $\mathrm{nNO}$ conducted in a large number of healthy children.

In the majority of the clinical studies on $\mathrm{nNO}$, comparisons are made with small "normal" control groups. There is only one study [27] that formally intended to establish normal nNO values in children. DAYA et al. [27] assessed $\mathrm{nNO}$ values in 30 healthy children, 18 males and 12 females aged between 3.2$17.6 \mathrm{yrs}$, and found a considerable variability, which may be ascribed to the racial heterogeneity (17 Caucasian, seven Oriental and six Black children) and the small size of the study group. In addition to this, there were only between one and four children assigned to each age category. The children were recruited from siblings or friends from patients attending an otolaryngology clinic, and may not represent a sample of the general population. Moreover, age and other potential confounders such as ambient NO were not taken into account.

On the basis of the current literature children with airway morbidity, recent infections ( $<1$ week) and recent adeno- and/or tonsillectomy ( $<3$ months) were excluded [3, 8, 10, 11, 13, 14, 16, $29,30,33,37-47]$. This also applied for smoking and children using airway-influencing medication. Physical exercise immediately before the measurements was not allowed. Sex, age, height, weight, BMI, history of adenoidectomy, passive smoking and ambient $\mathrm{NO}$ were considered as covariates.

In the current study, age was positively associated with nNO. The association was significant and especially evident in children $<12$ yrs of age. Radiological anatomy of the paranasal sinuses shows that sinuses reach their final size in 12-yr-olds $[48,49]$. Due to this, and in combination with the results of the multivariate modelling, the data with a break at the age of 12 yrs was analysed. The association between $\mathrm{nNO}$ and age in children $<12$ yrs was approximately three times stronger when compared with children aged $\geqslant 12$ yrs. In the latter 
group the association was no longer significant, indicating that age is an interaction factor. These findings are in agreement with the hypothesis that $\mathrm{nNO}$ concentrations are correlated with the anatomical development of the paranasal sinuses [48, 49]. An additional factor, explaining the association between age and $\mathrm{nNO}$ might also be the increase of the nasopharyngeal airway during pre- and early adolescence while adenoid regresses. The altered volume influences the intranasal flow and, perhaps, nNO measurements.

Adenoids develop during infancy and reach a maximal size between $2-14$ yrs [50]. In the present study nNO was significantly lower in children with a history of adenoidectomy. This association was only found in children aged $<12$ yrs, probably because after this age adenoids regress rapidly, making children with an adenoidectomy comparable with children without. Besides, removal of adenoids is more likely in case of chronic respiratory infections, which might cause elevated $\mathrm{nNO}[14,29,30]$.

Little is known about how to deal with the influence of ambient $\mathrm{NO}$ on $\mathrm{nNO}$. A significant relation was found between ambient and $\mathrm{nNO}$, ambient $\mathrm{NO}$ was $\sim 10 \%$ (median $43 \mathrm{ppb}$ ) of the mean nNO. Therefore, the presented absolute levels and the calculated output $(\mathrm{ppb} \times$ sample flow) may have been overestimated. This is a problem in the assessment of $\mathrm{nNO}$ as a diagnostic tool or monitoring tool in case of, for example, allergic rhinitis where there might be only subtle changes in $\mathrm{nNO}$, in contrast with, primary cilliary dyskinesia or CF where $\mathrm{nNO}$ is much lower than in healthy subjects. Several investigators have simply subtracted ambient $\mathrm{NO}$ from nNO $[16,43]$ without justification. The present data show that ambient $\mathrm{NO}$ and $\mathrm{nNO}$ are not simply additional, but that correction for $\mathrm{nNO}$ can be made by subtracting $0.50 \mathrm{ppb}$ per $\mathrm{ppb}$ of ambient NO. The fact that a relationship with ambient NO was found, which other studies have not, could be explained by the large range of ambient NO values (5$182 \mathrm{ppb}$ ) in the present study, whereas in most previous studies ambient NO did not exceed 20 ppb [9, 10, 14, 33].

Further studies in other populations should confirm whether the current prediction rules, subtracting $50 \%$ of ambient NO, have general validity. For the moment it seems prudent to include healthy controls in any studies exploring $\mathrm{nNO}$ in disease.

The present study used questionnaire-based information for inclusion, without physical examination and/or laboratory tests to confirm the health status of the studied subjects. The validity of such findings can be questioned. However, physical examination is not sensitive to detect allergic disease, and the questionnaires used are well validated in the ISAAC study and showed good agreement with objective tests of allergy $[35,36]$.

In conclusion, a normal reference range for nasal nitric oxide in healthy school children was established, and an algorithm developed to predict normal nasal nitric oxide on the basis of age, ambient nitric oxide and a history of adenoidectomy. Establishing the normal range of nasal nitric oxide in 6-17-yrold, healthy children is important for the investigation of the nasal nitric oxide measurement as a screening, or even diagnostic test for various inflammatory conditions of the upper airways, such as allergic rhinitis, cystic fibrosis or primary ciliary dyskinesia.

\section{ACKNOWLEDGEMENTS}

The authors would like to thank G.J.J.M. Borsboom for help regarding the statistical analysis. The authors would also like to express their gratitude to the three schools and all the children who participated in the study.

\section{REFERENCES}

1 Gustafsson LE, Leone AM, Persson MG, Wiklund NP, Moncada S. Endogenous nitric oxide is present in the exhaled air of rabbits, guinea pigs and humans. Biochem Biophys Res Commun 1991; 181: 852-857.

2 Alving K, Weitzberg E, Lundberg JM. Increased amount of nitric oxide in exhaled air of asthmatics. Eur Respir J 1993; 6: 1368-1370.

3 Lundberg JO, Rinder J, Weitzberg E, Lundberg JM, Alving K. Nasally exhaled nitric oxide in humans originates mainly in the paranasal sinuses. Acta Physiol Scand 1994; 152: 431-432.

4 Mancinelli RL, McKay CP. Effects of nitric oxide and nitrogen dioxide on bacterial growth. Appl Environ Microbiol 1983; 46: 198-202.

5 Lundberg JO, Farkas-Szallasi T, Weitzberg E, et al. High nitric oxide production in human paranasal sinuses. Nat Med 1995; 1: 370-373.

6 Runer T, Cervin A, Lindberg S, Uddman R. Nitric oxide is a regulator of mucociliary activity in the upper respiratory tract. Otolaryngol Head Neck Surg 1998; 119: 278-287.

7 Puybasset L, Rouby JJ, Mourgeon E, et al. Inhaled nitric oxide in acute respiratory failure: dose-response curves. Intensive Care Med 1994; 20: 319-327.

8 Colantonio D, Brouillette L, Parikh A, Scadding GK. Paradoxical low nasal nitric oxide in nasal polyposis. Clin Exp Allergy 2002; 32: 698-701.

9 Arnal JF, Didier A, Rami J, et al. Nasal nitric oxide is increased in allergic rhinitis. Clin Exp Allergy 1997; 27: 358-362.

10 Arnal JF, Flores P, Rami J, et al. Nasal nitric oxide concentration in paranasal sinus inflammatory diseases. Eur Respir J 1999; 13: 307-312.

11 Ferguson EA, Eccles R. Changes in nasal nitric oxide concentration associated with symptoms of common cold and treatment with a topical nasal decongestant. Acta Otolaryngol 1997; 117: 614-617.

12 Wodehouse T, Kharitonov SA, Mackay IS, Barnes PJ, Wilson R, Cole PJ. Nasal nitric oxide measurements for the screening of primary ciliary dyskinesia. Eur Respir J 2003; 21: 43-47.

13 Baraldi E, Azzolin NM, Biban P, Zacchello F. Effect of antibiotic therapy on nasal nitric oxide concentration in children with acute sinusitis. Am J Respir Crit Care Med 1997; 155: 1680-1683.

14 Kharitonov SA, Rajakulasingam K, O'Connor B, Durham SR, Barnes PJ. Nasal nitric oxide is increased in patients with asthma and allergic rhinitis and may be modulated by nasal glucocorticoids. J Allergy Clin Immunol 1997; 99: 58-64.

15 Vural C, Gungor A. The effect of topical fluticasone on nasal nitric oxide levels in a patient with allergic rhinitis. Ear Nose Throat J 2003; 82: 592-597. 
16 Vural C, Gungor A. Variations of nasal nitric oxide in a subject with allergic rhinitis: a longitudinal study. Am J Otolaryngol 2002; 23: 191-195.

17 Dotsch J, Puls J, Klimek T, Rascher W. Reduction of neuronal and inducible nitric oxide synthase gene expression in patients with cystic fibrosis. Eur Arch Otorhinolaryngol 2002; 259: 222-226.

18 Dotsch J, Demirakca S, Terbrack HG, Huls G, Rascher W, Kuhl PG. Airway nitric oxide in asthmatic children and patients with cystic fibrosis. Eur Respir J 1996; 9: 2537-2540.

19 Kelley TJ, Drumm ML. Inducible nitric oxide synthase expression is reduced in cystic fibrosis murine and human airway epithelial cells. J Clin Invest 1998; 102: 1200-1207.

20 Thomas SR, Kharitonov SA, Scott SF, Hodson ME, Barnes PJ. Nasal and exhaled nitric oxide is reduced in adult patients with cystic fibrosis and does not correlate with cystic fibrosis genotype. Chest 2000; 117: 1085-1089.

21 Grasemann H, Gartig SS, Wiesemann HG, Teschler H, Konietzko N, Ratjen F. Effect of L-arginine infusion on airway NO in cystic fibrosis and primary ciliary dyskinesia syndrome. Eur Respir J 1999; 13: 114-118.

22 Ruckes-Nilges C, Lindemann H, Klimek T, Glanz H, Weber WM. Nitric oxide has no beneficial effects on ion transport defects in cystic fibrosis human nasal epithelium. Pflugers Arch 2000; 441: 133-137.

23 Horvath I, Loukides S, Wodehouse T, et al. Comparison of exhaled and nasal nitric oxide and exhaled carbon monoxide levels in bronchiectatic patients with and without primary ciliary dyskinesia. Thorax 2003; 58: 68-72.

24 Noone PG, Leigh MW, Sannuti A, et al. Primary ciliary dyskinesia: diagnostic and phenotypic features. Am J Respir Crit Care Med 2004; 169: 459-467.

25 Narang I, Ersu R, Wilson NM, Bush A. Nitric oxide in chronic airway inflammation in children: diagnostic use and pathophysiological significance. Thorax 2002; 57: 586-589.

26 Lindberg S, Cervin A, Runer T. Low levels of nasal nitric oxide (NO) correlate to impaired mucociliary function in the upper airways. Acta Otolaryngol 1997; 117: 728-734.

27 Daya H, Qian W, McClean P, et al. Nasal nitric oxide in children: a novel measurement technique and normal values. Laryngoscope 2002; 112: 1831-1835.

28 Djupesland PG, Chatkin JM, Qian W, Haight JS. [Nitric oxide in the nose and paranasal sinuses-respiratory tract physiology in a new perspective]. Tidsskr Nor Laegeforen 1999; 119: 4070-4072.

29 Lundberg JO. Airborne nitric oxide: inflammatory marker and aerocrine messenger in man. Acta Physiol Scand Suppl 1996; 633: 1-27.

30 Henriksen AH, Sue-Chu M, Lingaas Holmen T, Langhammer A, Bjermer L. Exhaled and nasal NO levels in allergic rhinitis: relation to sensitization, pollen season and bronchial hyperresponsiveness. Eur Respir J1999;13:301-306.

31 Kharitonov SA, Barnes PJ. Nasal contribution to exhaled nitric oxide during exhalation against resistance or during breath holding. Thorax 1997; 52: 540-544.

32 Lewandowski $\mathrm{K}$, Busch $\mathrm{T}$, Lohbrunner $\mathrm{H}$, et al. Low nitric oxide concentrations in exhaled gas and nasal airways of mammals without paranasal sinuses. J Appl Physiol 1998; 85: 405-410.
33 Lindberg S, Cervin A, Runer T. Nitric oxide (NO) production in the upper airways is decreased in chronic sinusitis. Acta Otolaryngol 1997; 117: 113-117.

34 Struben VMD, Wieringa MH, Mantingh CJ, Bommeljé CC, de Jongste JC, Feenstra L. Standardisation of nasal NO measurement. Eur Respir J 2004; 24: Suppl. 48, 270s.

35 Asher MI, Keil U, Anderson HR, et al. International Study of Asthma and Allergies in Childhood (ISAAC): rationale and methods. Eur Respir J 1995; 8: 483-491.

36 Asher MI, Weiland SK. The International Study of Asthma and Allergies in Childhood (ISAAC). ISAAC Steeriing Committee. Clin Exp Allergy 1998; 28: Suppl 5, 52-66. Discussion 90-91.

37 Artlich A, Busch T, Lewandowski K, Schaible T, Falke KJ, Gortner L. Exhaled nitric oxide in preterm infants. Respir Physiol 1998; 114: 195-200.

38 Giraud GD, Nejadnik B, Kimberly B, Holden WE. Physical characteristics and gas composition of nasal air affect nasal nitric oxide release. Respir Physiol 1998; 114: 285-296.

39 Imada M, Iwamoto J, Nonaka S, Kobayashi Y, Unno T. Measurement of nitric oxide in human nasal airway. Eur Respir J 1996; 9: 556-559.

40 Qian W, Djupesland PG, Chatkin JM, et al. Aspiration flow optimized for nasal nitric oxide measurement. Rhinology 1999; 37: 61-65.

41 Bartley J, Fergusson W, Moody A, Wells AU, Kolbe J. Normal adult values, diurnal variation, and repeatability of nasal nitric oxide measurement. Am J Rhinol 1999; 13: 401-405.

42 Kharitonov SA, Logan-Sinclair RB, Busset CM, Shinebourne EA. Peak expiratory nitric oxide differences in men and women: relation to the menstrual cycle. $\mathrm{Br}$ Heart J 1994; 72: 243-245.

43 Silkoff PE, Chatkin J, Qian W, et al. Nasal nitric oxide: a comparison of measurement techniques. Am J Rhinol 1999; 13: 169-178.

44 Arnal JF, Tack I, Besombes JP, Pipy B, Negre-Salvayre A. Nitric oxide and superoxide anion production during endothelial cell proliferation. Am J Physiol 1996; 271: C1521-526.

45 Recommendations for standardized procedures for the online and off-line measurement of exhaled lower respiratory nitric oxide and nasal nitric oxide in adults and children1999. This official statement of the American Thoracic Society was adopted by the ATS Board of Directors, July 1999. Am J Respir Crit Care Med 1999; 160: 2104-2117.

46 Qian W, Chatkin JM, Djupesland PG, et al. Unilateral nasal nitric oxide measurement after nasal surgery. Ann Otol Rhinol Laryngol 2000; 109: 952-957.

47 Kirihene RK, Rees G, Wormald PJ. The influence of the size of the maxillary sinus ostium on the nasal and sinus nitric oxide levels. Am J Rhinol 2002; 16: 261-264.

48 Weiglein A, Anderhuber W, Wolf G. Radiologic anatomy of the paranasal sinuses in the child. Surg Radiol Anat 1992; 14: 335-339.

49 Jones $\mathrm{N}$. The nose and paranasal sinuses physiology and anatomy. Adv Drug Deliv Rev 2001; 51: 5-19.

50 Jaw TS, Sheu RS, Liu GC, Lin WC. Development of adenoids: a study by measurement with MR images. Kaohsiung J Med Sci 1999; 15: 12-18. 